\title{
Development of Low Pressure Exhaust Gas Recirculation System
} for Exhaust Gas Emission Control of Mitsubishi UE Diesel Engine

At the MEPC66, it was decided that as of 2016, IMO Tier III regulations would require nitrogen oxides (NOx) reductions of approx. 76\% from Tier II levels. To comply with IMO Tier III regulations, we have developed a low pressure Exhaust Gas Recirculation (LP-EGR) system that has strong NOx reduction potential. It has been confirmed through studies using our 4UE-X3 test engine that the NOx emissions of our LP-EGR system comply with IMO Tier III regulations and that the increase in fuel consumption was less than 1.5\%. Recently, an engine integrating almost every component of the LP-EGR system was applied to the $4 \mathrm{UE}-\mathrm{X} 3$. Through tests and evaluations of this system, we carefully worked out the consumption volumes and life-cycle costs of our LP-EGR system. As a result, the system is IMO Tier III regulation-compliant and offers advanced environmental protection and user-benefits.

\section{1. はじめに}

船舶から排出される大気污染物質に関する規制は 年々缓しくなり, 2010 年 7 月に MARPOL73/78 条約 の附属書 VI 改正案が発効し, 現在に至っている.

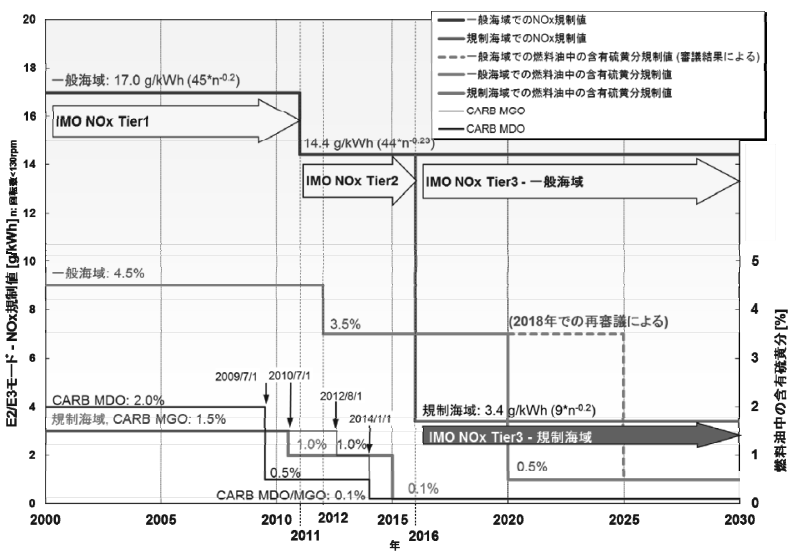

図 1 IMO による NOx, SOx 規制

図 1 に示すように 2016 年から始まるNOx Tier3 規制 では, NECA(NOx 排出規制海域:NOx Emission Control Area)において現行の Tier2 に対して約 76\%

*原稿受付 平成 27 年 3 月 18 日.

**三菱重工舶用機械エンジン株式会社

(神戸市兵庫区和田崎町 1-1-1)
の削減が必要となる．そのため，当社においても様々 な NOx 削減技術の開発を行ってきた。本稿では，当 社の中で開発してきた NOx 低減技術の中でも単独で $80 \%$ 以上削減可能である低圧 EGR(Exhaust Gas Recirculation)システムの開発について述べる.

\section{N0x 低減技術}

一般的に NOx を削減する技術としては、図 2 に示す とおりである.

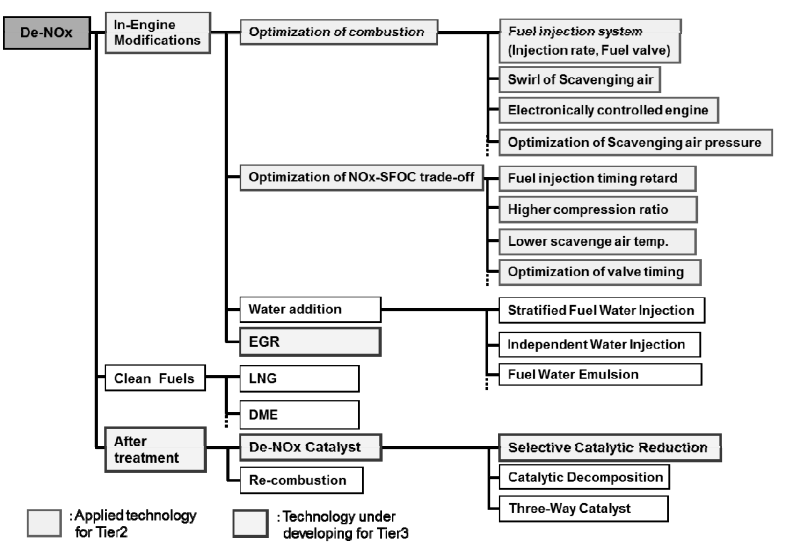

図 2 NOx 削減技術マップ 
である Tier2 規制までは燃料噴射タイミングリタード, 燃料弁噴孔アレンジや掃排気系の最適化等の所謂エン ジン内部のチューニングで対応している. しかしなが ら，大幅な NOx 削減が必要となる Tier3 規制ではエ ンジン内部のチューニングレベルでは適合できないた め, 大きく分けて 2 つの方式で対応することとなる.

1 つは排ガス後処理技術である SCR (Selective Catalytic Reduction), もう1つはエンジン内の燃焼状 態を変化させて NOx を低減する EGR である.

表 $1 \mathrm{NOx}$ 低減技術比較

\begin{tabular}{|c|c|c|c|c|c|}
\hline 调目 & NOx低渎祅果(Tira1比) & 紫貫怼化 & 技開レハル & 制期投筫 & ランニングコスト \\
\hline 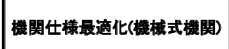 & $\Delta \mathbf{2 0 \%}$ & $+2 \sim+396$ & $\begin{array}{l}\text { 現存技術に } \\
\text { 对応可能 }\end{array}$ & 小 & 小 \\
\hline 電子制御椎関 & $\Delta 20 \%$ & $0 \sim+1 \%$ & 開発高 & 中 & 小 \\
\hline \multirow{3}{*}{ 水揊射装置 } & $\begin{array}{l}\text { 水エマルジョン燃料: } \\
\Delta 50 \%\end{array}$ & $+2 \sim+3 \%$ & 開吪済 & 中 & 中 \\
\hline & 独立水噴射: $\Delta B 0 \%$ & $\begin{array}{l}+7 \sim \\
+10 \%\end{array}$ & 開吪済 & 中 & 中 \\
\hline & 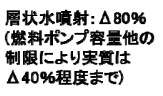 & 約 $+10 \%$ & 開畔済 & 中 & 中 \\
\hline スクラハイー付EGR装置 & $\Delta 80 \%$ & $+1 \sim 3 \%$ & 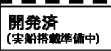 & 大 & 中 \\
\hline SCR & $\Delta 80 \sim 90 \%$ & $0 \sim+1 \%$ & 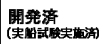 & 大 & 大 \\
\hline
\end{tabular}

\section{EGR システム}

\subsection{EGR システムの概要}

近年，EGR システムは自動車，発電機を代表する 中・小型エンジンに適用されている. EGR システム を搭載したエンジンは，排ガスの一部を吸気に戻すこ とで然焼室内の酸素濃度を下げ，且つ排ガスに含まれ る $\mathrm{H}_{2} \mathrm{O}, \mathrm{CO}_{2}$ 等の不活性ガスの割合を増し熱容量を大 きくすることで，燃焼ガス温度の上昇を抑え $\mathrm{NOx}$ 生 成反応を抑制する技術である。

\section{2 舶用ディーゼルエンジンにおける EGR}

EGR システムを舶用ディーゼルエンジンに適用し た際，その排気ガスを取込む位置によって，図 3 に示 すように低圧と高圧 EGR の 2 つの種類に分類するこ とができる。

低圧 EGR システムにおいては, 排ガスは過給機のタ ービン後流より分岐され過給機吸込み側に戻す。一方 で，高圧 EGR システムにおいては，排ガスは過給機 タービン上流で分岐され，掃気トランクへ戻すシステ ムの構成となっている.

これらの EGR システムの特徵は, 分岐位置における 排ガスの特徵によって決定される。例えば低圧 EGR システムは，排ガスが比較的低圧，低温であるため, EGR システムの構成が, より簡易である利点がある. また，過給機吸込み側がガスを誘引するため，高圧
EGR に比べ，EGR ブロア容量が小さい. しかしなが ら，低圧であるため，排ガス容積が大きくなり，装置 が大きくなってしまう短所がある. 高圧 EGR システ ムでは，高圧であるため, 排ガスの容積が小さく装置 がコンパクトであるという利点があるが，高温，高圧 であるため，排ガス洗浄装置であるスクラバをはじめ として，装置が複雑であり，また，排ガス圧力を掃気 圧レベルまで昇圧する必要があるため， EGR ブロア の容量が大きくなってしまう短所がある。これらの理 由から，当社は，低圧 EGR システムを選択し，開発 してきた.
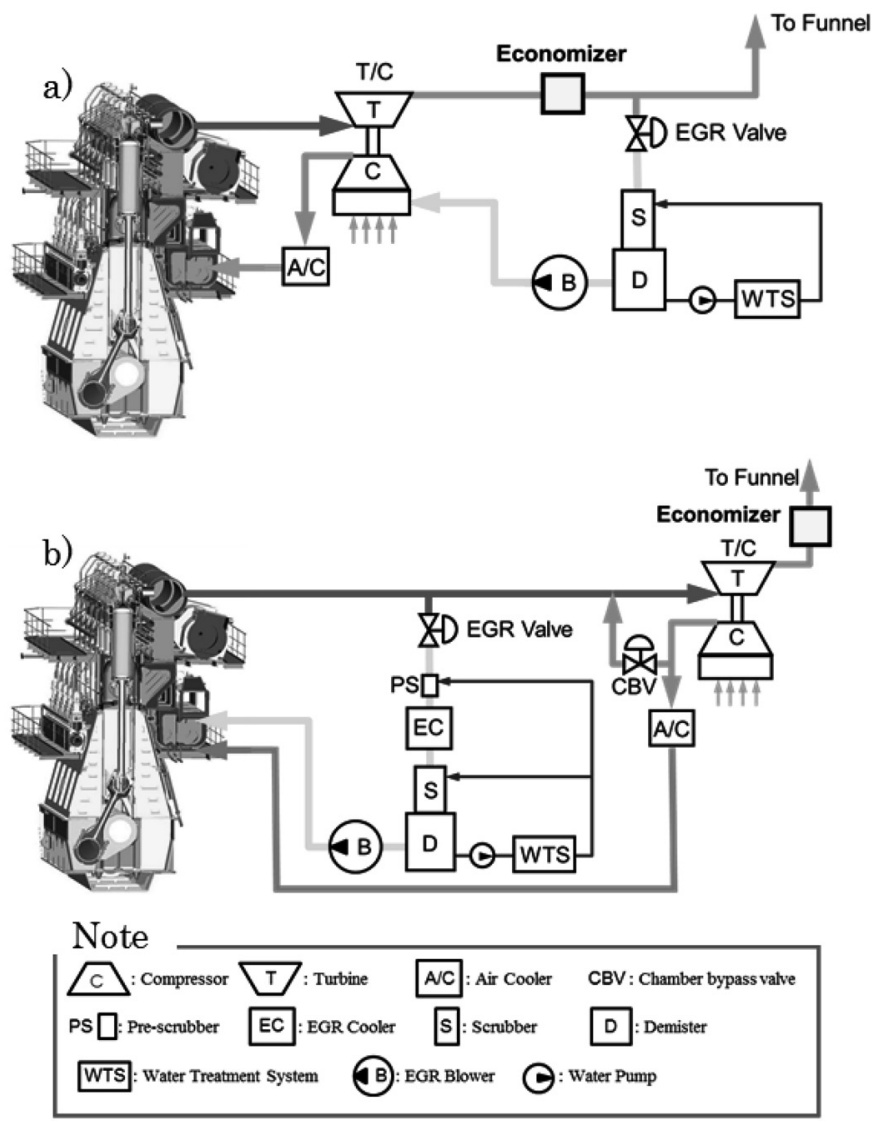

図 3 a) 低圧 EGR システム，b）高圧 EGR システム

\section{3 低圧 EGR システムの概要}

低圧 EGR システムの概要は以下の通りである.

(1) 過給機もしくは排ガスエコノマイザ後流より， 排ガスの一部が EGR ガスとして分岐される.

(2) 分岐された EGR ガスはEGR ラインへと導かれ， それ以外のガスは，煙突から船外一排出される.

(3) EGR ガスは, 排ガス洗浄装置であるスクラバで sootと SOx が除去される.

(4) その後, EGR ガスは, EGR ブロアで昇圧され, 過給機吸込み側入導かれる.

(5) 過給機のコンプレッサで EGR ガスと新気は混 合，圧縮され，エンジンへと導入される. 


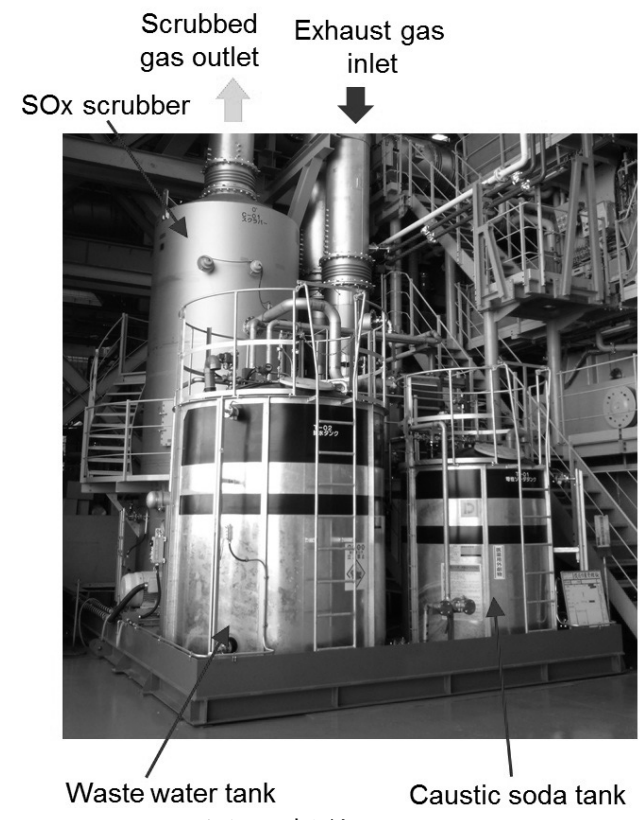

図 4 新型スクラバ
舶用ディーゼルエンジンは, MDO やHFO といった 残渣油を多く含んだ然料を使用しており，排ガスは多 くの soot やSOx を含む. 加えて，その排ガス量は膨 大な量であるため, EGR ガスを洗浄するスクラバは, 非常に重要な装置である. そのため, 当社では図 4 に 示すようなイナートガススクラバをベースとした新型 スクラバを開発した。 このスクラバでは，水を使用し 排ガスを洗浄する. 排ガスを洗浄した後の水は，遠心 分離機からなる水処理装置で soot を分離, $\mathrm{pH}$ を調整 した後, 再利用する.

低圧 EGR システムの開発においては, これらの装置 を組み合わせ，エンジン，スクラバ及び水処理装置の 性能を確認した. 目標性能としては, NOx 削減率 $80 \%$ 以上, 燃費悪化率 $3 \%$ 以下, SOx 除去率 $98 \%$ 以上, soot 除去率 $75 \%$ 以上とした.

\section{4. 試験結果}

低圧 EGR システムを単筒試験機 NC33 および 4UEC60LSE-Eco をべースとしたフルスケール試験 エンジン 4UE-X3 で試験した結果を以下に示す.

\section{1 スクラバ性能}

スクラバの試験結果を図 5,6 に示す. なお, 試験で は, $\mathrm{SOx}$ は $\mathrm{SO}_{2}$ として計測した. 試験結果から, スク ラバは 80\%以上の soot 及び，95\%以上の SOx を除去 可能であることが確認できた. SOx 除去率は目標值よ り低いが，スクラバ出口における SOx は数 ppm 程度 であり, 計測器の誤差の範囲内である. そのため, こ のスクラバは実使用においても目標を達成可能である
と言える.

本試験結果を踏まえ, 多くの設計と試験を重ねた結 果，本スクラバは小型化に成功しており，図 7 に示す 通り，エンジン上に搭載することが可能となった。 こ のエンジン搭載型スクラバにおいても同様の除去性能 を確認できており，装置が大きくなりがちという低圧 EGRの短所を克服することができた.

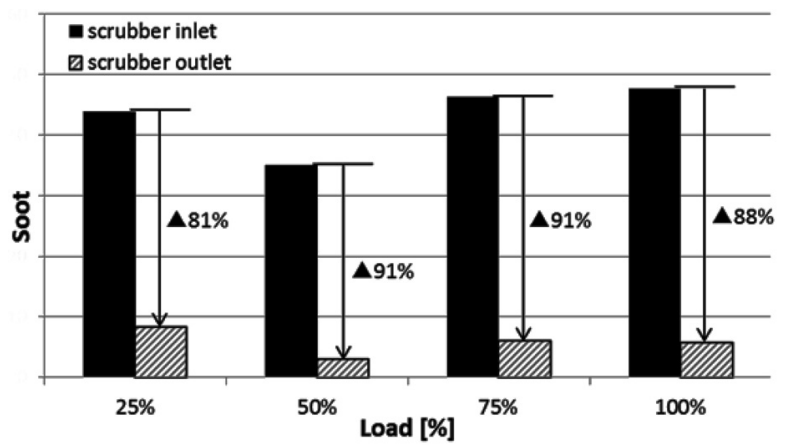

図 5 Soot 除去率

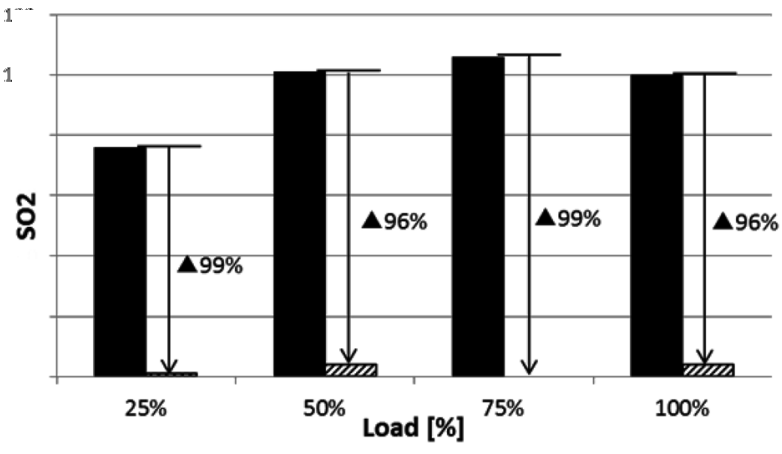

図 $6 \mathrm{SO}_{2}$ 除去率

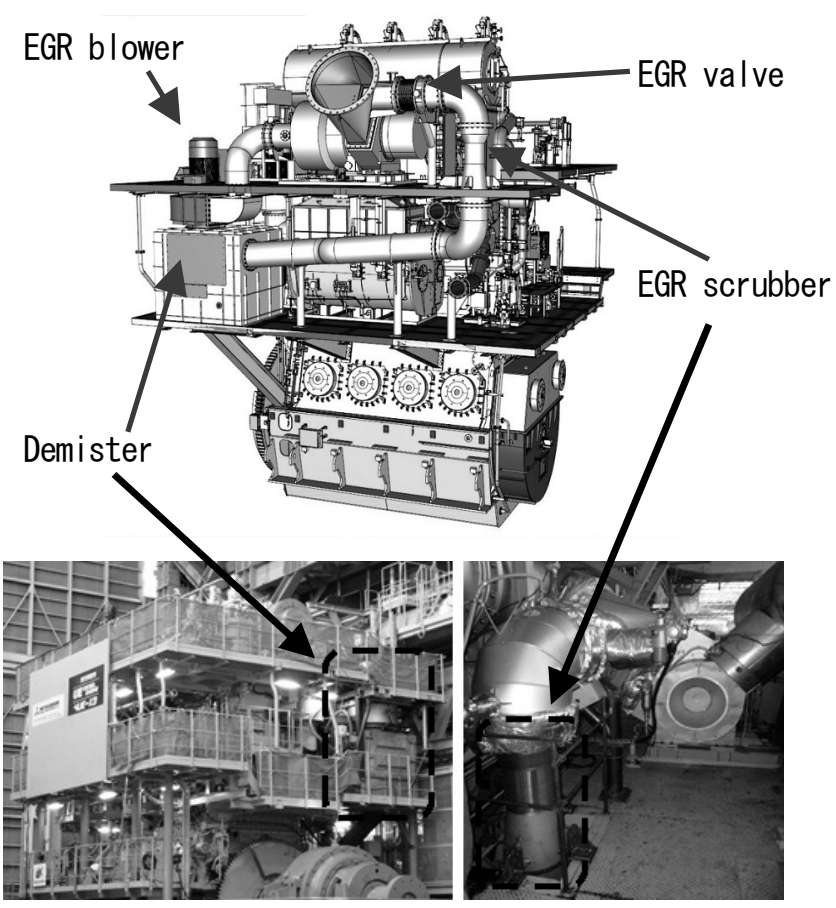

図 7 エンジン搭載型 EGR システムの $3 \mathrm{D}$ 図(上), 実際の デミスタ及びEGR スクラバ(下) 


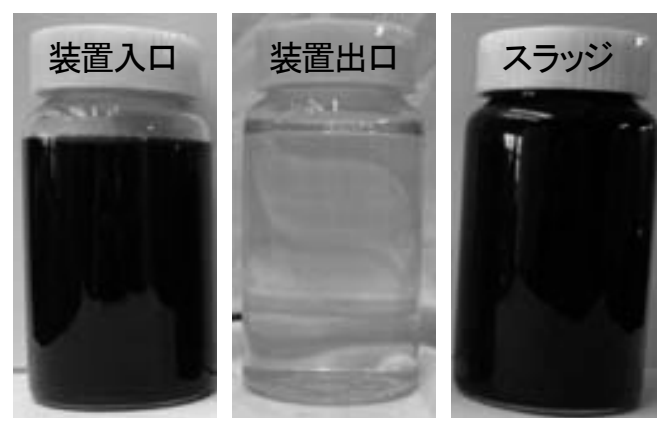

図 8 水処理装置試験結果: 水処理装置入口 (左), 出口 (中央), 分離されたスラッジ(右)

水処理装置に関しても図 8 に示寸通り, スクラバ洗 浄水からスラッジを分離できることが確認できた.

\section{2 エンジン性能}

エンジン性能検証試験においては，電子制御システ ムである Eco システムにより，燃料噴射タイミング, 排気弁タイミング等のエンジンパラメータを最適化 した.

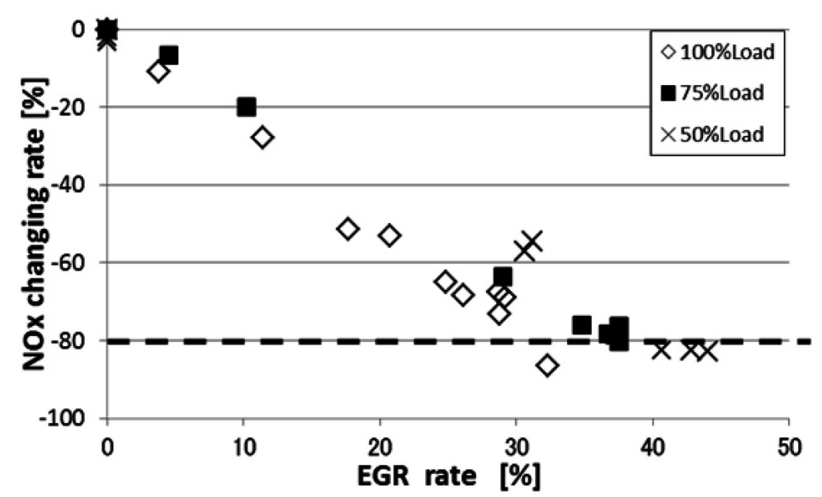

図 9 低圧 EGR における NOx 削減率

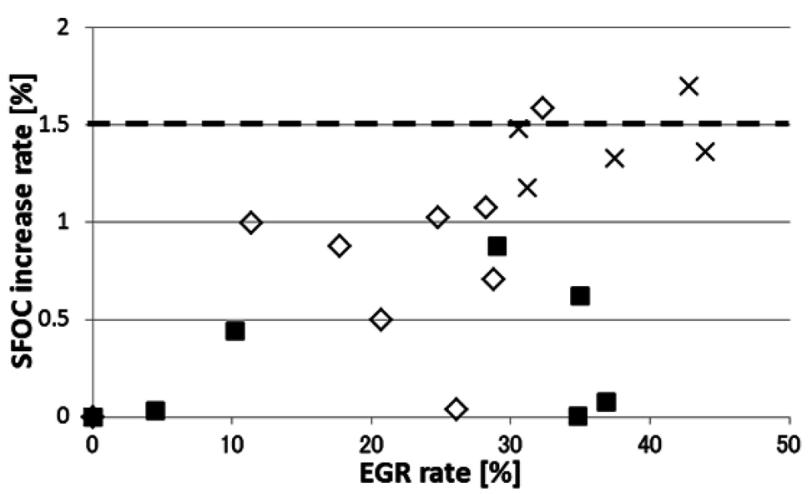

図 10 低圧 EGR における然費悪化率

試験結果を図 9，10 に示す. 図に示すように，全負 荷において燃費悪化率を約 $1.5 \%$ 以下に抑制し， NOx を $80 \%$ 以上削減可能であり、NOx Tier3 規制に適合で きることが確認できた.

\section{3 試験後のエンジン内部の状況}

低圧 EGR の試験を約 $150 \mathrm{hr}$ 実施した後にエンジン 内部を点検した．点検時の燃焼室の様子を図 11 に示 す．リング，ライナ共に異常な摩耗等は見られず，良 好な状態であった。

これらの結果から，当社の低圧 EGR システムは, NOx Tier3 規制を達成可能であり，また個々のシス テム構成装置は, 要求する性能を満たしていることを 確認することができた.
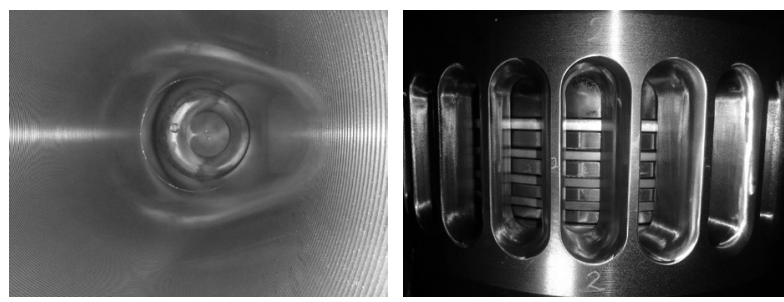

図 11 試験後のリング(左), ライナ(右)の状況

\section{5. ライフサイクルコスト}

これまでの試験結果をもとに装置の初期コスト，シ ステムのユーティリティを算出し，低圧 EGR システ ムのライフサイクルコストを算出した．また，その結 果を他のNOx Tier3 対応技術である高圧EGR及び低圧 SCR と比較した. 比較結果を図 12 に示寸.

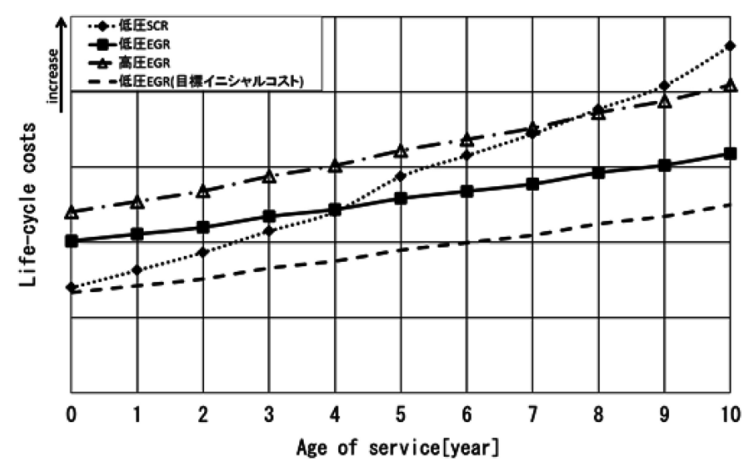

図 12 ライフサイクルコストの比較

比較の際の前提条件は以下のとおりである.

$>$ 運航時間 : 総計 $6720 \mathrm{hr} / \mathrm{year}$ にて ECA 運航時 間を $5 \%(336 \mathrm{hr} / \mathrm{year})$ 含む.

> 初期コスト : 低圧 EGR は開発実績に基づき算 出. 高圧 EGR, 低圧 SCR は調査結果から算出.

$>$ 燃料油 : SCR は低硫黄然料, EGR は従来の C 重油(硫黄分 $3.5 \%$ 含有) とした.

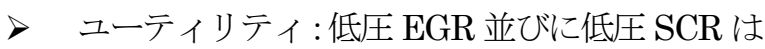
当社の試験結果から, 高圧 EGR は調査結果を もとに算出した. 
低圧 EGR と高圧 EGR を比較した場合, 低圧 EGR はその EGR ガスの圧力, 温度の低さから構成装置の 数や強度が低くて済むため, 初期コス卜は低圧 EGR のほうが安くなる。.また, 運用コストにおいても低圧 EGR のほうが有利である.それは, 前述のとおり EGR ブロアの動力が低く済むことに加え, 低圧 EGR は排 ガスエコノマイザ後流からも排ガスを分岐し， EGR ガスとすることができ，全排ガスが排ガスエコノマイ ザを通るため, エコノマイザは通常通りの運用が可能 である.しかしながら，高圧 EGR においては，過給 機前から EGR ガスを分岐する必要があるため， EGR 時はエコノマイザを通過するガス量が低下し，追い焚 きが必要となってしまう。このライフサイクルコスト の比較においては, 低圧 SCR は低硫黄然料の使用の ため,最もライフサイクルコストが高い結果となった。 これらの結果から, 低圧 EGR はライフサイクルコス トの面でその優位性を確認することができた。

\section{6. まとめ}

試験エンジンでの試験により，NOx Tier3 に適合す る低圧 EGR システムを開発することができた. また, この試験結果に基づきシステムのユーティリティ及び ライフサイクルコストを算出し，その優位性を確認す ることができた.

\section{7. 今後の予定}

低圧 EGR の開発における次の段階としては, 実船搭 載試験により長期信頼性の評価を予定している.

\section{参考文献}

(1) K. Sakaguchi, and M. Sugihara, "The development of the electronically controlled engine, MITSUBISHI UEC Eco-Engine", CIMAC Congress 2004, Kyoto, (2004), paper No.221

(2) K. Imanaka, J. Yanagi, A. Miyanagi, and K. Watanabe, "Exhaust Emission Control of Mitsubishi UE Diesel Engine", Proc. of ISME Kobe, (2011), C5-2.

(3) N. Hiraoka, K. Imanaka, "Exhaust Emission Control of Mitsubishi UE Diesel Engine", CIMAC Congress 2013, Shanghai, (2013), paper No. 418

\section{著者紹介}

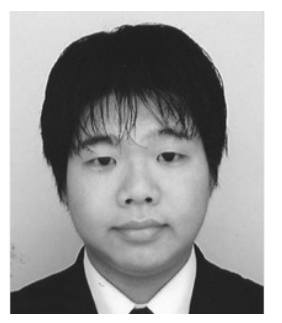

上田 哲司

- 1983 年生.

・ 三菱重工舶用機械エンジン(株)

- 東京工業大学修士課程

·専門分野 : 環境対応技術・ 機関性能 